\title{
Development and exploitation of a novel mutant androgen receptor modelling strategy to identify new targets for advanced prostate cancer therapy
}

\author{
Daniel O'Neill², Dominic Jones ${ }^{1}$, Mark Wade ${ }^{1}$, James Grey ${ }^{1}$, Sirintra Nakjang ${ }^{1}$, \\ Wenrui Guo ${ }^{1}$, David Cork ${ }^{1}$, Barry R. Davies ${ }^{2}$, Steve R. Wedge ${ }^{1}$, Craig N. Robson ${ }^{1}$, \\ Luke Gaughan ${ }^{1}$ \\ ${ }^{1}$ Northern Institute for Cancer Research, Newcastle University, Newcastle Upon Tyne, NE2 4HH, UK \\ ${ }^{2}$ AstraZeneca, Innovative Medicines, Discovery Sciences, Cambridge Science Park, Cambridge, CB4 OWG, UK \\ Correspondence to: \\ Luke Gaughan, e-mail: luke.gaughan@ncl.ac.uk \\ Keywords: prostate cancer, androgen receptor, mutation, anti-androgen-resistance, SGK 1 \\ Received: March 04, $2015 \quad$ Accepted: July 08, $2015 \quad$ Published: July 20, 2015
}

\section{ABSTRACT}

The persistence of androgen receptor (AR) signalling in castrate-resistant prostate cancer (CRPC) highlights the unmet clinical need for the development of more effective AR targeting therapies. A key mechanism of therapy-resistance is by selection of AR mutations that convert anti-androgens to agonists enabling the retention of androgenic signalling in CRPC. To improve our understanding of these receptors in advanced disease we developed a physiologically-relevant model to analyse the global functionality of AR mutants in CRPC. Using the bicalutamideactivated $A R_{\mathrm{w} 741 \mathrm{~L} / \mathrm{c}}$ mutation as proof of concept, we demonstrate that this mutant confers an androgenic-like signalling programme and growth promoting phenotype in the presence of bicalutamide. Transcriptomic profiling of $A R_{\text {w741L }}$ highlighted key genes markedly up-regulated by the mutant receptor, including TIPARP, RASD1 and SGK1. Importantly, SGK1 expression was found to be highly expressed in the KUCaP xenograft model and a CRPC patient biopsy sample both of which express the bicalutamide-activated receptor mutant. Using an SGK1 inhibitor, $A R_{\text {w741L }}$ transcriptional and growth promoting activity was reduced indicating that exploiting functional distinctions between receptor isoforms in our model may provide new and effective therapies for CRPC patients.

\section{INTRODUCTION}

Prostate cancer (PC) is the leading cause of male cancer deaths in the western world and remains a major challenge to treat effectively $[1,2]$. At presentation, PC growth is androgen-dependent hence the mainstay for treatment is hormone-ablation therapy using antiandrogens and/or androgen-deprivation therapies (ADT) $[3,4]$. These act to repress the androgen receptor (AR), a member of the nuclear hormone receptor family of transcription factors that regulates expression of genes involved in prostate growth and transformation. By directly competing for androgen binding, anti-androgens such as bicalutamide, prevent activation of the AR and hence cause tumour regression $[3,5]$. Unfortunately, the cancer invariably re-appears in an androgen-independent form, termed castrate-resistant PC (CRPC), that is largely fatal. Importantly, the AR signalling axis is active in this advanced stage of disease and thus remains a suitable therapeutic target $[2,6]$. Indeed, the development of second generation anti-androgen and ADT therapies, such as enzalutamide [7], ARN-509 [8] and abiraterone [9] have shown promise in the treatment of CRPC. However, response rates of just $50 \%$ and the development of resistance has limited their success in the clinic [10-12].

Aberrant AR signalling is a hallmark of CRPC and is driven by numerous mechanisms including $A R$ gene amplification [13], somatic receptor mutation [14, 15], expression of AR splice variants [16] and de-regulated cofactor expression $[17,18]$ that facilitate receptor activity in castrate conditions and contribute to treatment failure. Post-translational modification of the AR represents an 
additional level of receptor regulation with acetylation of key residues in the hinge region of the receptor playing a pivotal role in contact-independent growth and tumour development in vivo [19].

The acquisition of AR mutations during ADT, that either facilitate transcriptional activity of the receptor in the absence of androgens or switch anti-androgens to AR agonists, is a well characterised mechanism of hormone escape and has been reported to occur in upwards of $60 \%$ of CRPC patients [3, 14]. Importantly, the frequency of AR mutations in primary disease is low, but is elevated in advanced disease through therapy-specific selection of aberrantly functioning receptors $[14,15]$. For example, chronic treatment with the anti-androgens bicalutamide and flutamide regularly drives selection of respective $\mathrm{AR}_{\mathrm{W} 741 \mathrm{~L} / \mathrm{C}}$ and $\mathrm{AR}_{\mathrm{H} 874 \mathrm{Y}} / \mathrm{AR}_{\mathrm{T} 877 \mathrm{~A}}$ mutations that utilise the agents as agonists to promote androgenic signalling and tumour cell growth [1]. More recently, the identification of an $\mathrm{AR}_{\mathrm{F} 876 \mathrm{~L}}$ mutation in patient samples refractory to enzalutamide and ARN-509 therapies has indicated that this is a phenomenon not limited to first-generation antiandrogens [20-22].

Modelling the function of CRPC-relevant AR mutants in their native context is challenging with most studies utilising non-PC cell lines, ectopicallyexpressed variant receptors and luciferase reporter-based transcriptional assays $[15,23,24]$. Outside of $\mathrm{LNCaP}$ cell studies, that express the $\mathrm{AR}_{\mathrm{T} 877 \mathrm{~A}}$ mutant, there is a paucity of information on the functional dynamics and global transcriptomics of CRPC-associated AR mutants in a physiological setting that is likely to provide key biomarkers and additional treatment regimens for antiandrogen-resistant malignancies. Moreover, a major consideration for the development of next-generation ARtargeted therapies is whether they will be effective against pre-existing AR mutants in CRPC hence the development of key research tools to facilitate these studies is of high priority. To address this, we have developed a novel RNAi-rescue approach that utilises stable expression of specific AR mutants in $\mathrm{LNCaP}$ cells depleted of the endogenous receptor to facilitate more robust analyses of aberrant receptor signalling. Therefore, it is now possible to assess global transcriptional activity and sensitivity of CRPC-associated AR mutants to new receptor-targeting agents in a more relevant cellular context. Using the $\mathrm{AR}_{\mathrm{w} 741 \mathrm{~L}}$ variant as a paradigm, we demonstrate that this mutant activates several endogenous AR-target genes, including PSA and TMPRSS2, and promotes a hyperproliferative phenotype in the presence of bicalutamide; a phenomenon that can be reversed by depletion of $\mathrm{AR}_{\mathrm{W} 741 \mathrm{~L}}$. Global transcriptomics identified a sub-set of $\mathrm{AR}_{\mathrm{w} 741 \mathrm{~L}^{-}}$ driven genes that are markedly up-regulated compared to the endogenous receptor, including SGK1, TIPARP and $R A S D 1$. Importantly, treatment with an SGK inhibitor down-regulated bicalutamide-driven receptor activity and cell growth, suggesting this could be a novel avenue of treatment for bicalutamide-resistant patients. In all, we have successfully applied a novel AR replacement strategy to physiologically model the $\mathrm{AR}_{\mathrm{w} 74 \mathrm{~L}}$ mutation in disease and highlighted key distinctions in receptor activity that could be therapeutically-exploited for improved CRPC treatment.

\section{RESULTS}

\section{Generation of an RNAi-rescue strategy for testing AR mutant activity}

There is a paucity of physiologically-relevant information on the distinct functionality of CRPCassociated AR mutants and how they drive aggressive PC malignancy. Studies to date have primarily utilised reporter-based assays incorporating ectopically-expressed mutant receptors to assess activity and sensitivity to receptor-targeting agents in AR null cell lines [14]. Although useful to demonstrate that specific CRPCassociated receptor mutants are activated by distinct ligands and down-regulated by first- and second-generation anti-androgens, as demonstrated in Supplementary Figures S1A and S1B, the failure to assess global functionality of these aberrantly functioning receptors in this context is a major problem. Improved models for examining CRPC-relevant AR mutations are therefore required. To address this, we developed a more physiological readout for AR mutant activity using an siRNA-mediated receptor replacement strategy in the androgenic LNCaP PC cell line. Using the bicalutamide-activated $\mathrm{AR}_{\mathrm{W} 741 \mathrm{~L}}$ as a paradigm for this study (Supplementary Figure S1), in part due to its relevance in current clinical practise, we generated an $\mathrm{LNCaP}$ derivative that stably expressed FLAG-tagged $\mathrm{AR}_{\mathrm{w} 741 \mathrm{~L}}$, called $\mathrm{LNCaP}-\mathrm{AR}_{\mathrm{w} 741 \mathrm{~L}}$ (Figure 1A). We next designed siRNA oligonucleotides (termed siAR $\left.{ }_{\mathrm{T} 877 \mathrm{~A}}\right)$ to discriminately deplete endogenous $\mathrm{AR}_{\mathrm{T} 877 \mathrm{~A}}$ (approximately $90 \%$ knockdown) by targeting the 3 '-UTR of the AR transcript that is absent in ectopicallyexpressed $\mathrm{AR}_{\mathrm{W} 741 \mathrm{~L}}$ mRNA (see Supplementary Table $\mathrm{S} 2$ for sequences). These oligonucleotides downregulated endogenous $\mathrm{AR}$ and PSA levels in $\mathrm{LNCaP}$ cells (Supplementary Figure S2A) and attenuated DHTinduced $\mathrm{AR}_{\mathrm{T} 877 \mathrm{~A}}$ recruitment to cis-regulatory elements of the PSA gene (Supplementary Figure S2B). Importantly, $\mathrm{siAR}_{\mathrm{T} 877 \mathrm{~A}}$ failed to reduce levels of ectopically-expressed FLAG-AR in PC3 cells, while an oligonucleotide targeted to the coding region of the AR (siAR) down-regulated expression of this protein (Supplementary Figure S3A and $\mathrm{S} 3 \mathrm{~B})$. In the context of the $\mathrm{LNCaP}-\mathrm{AR}_{\mathrm{w} 74 \mathrm{~L}}$ cell line, as expected, siAR ${ }_{\mathrm{T} 877 \mathrm{~A}}$ reduced endogenous $\mathrm{AR}$ levels, but did not affect expression of the $\mathrm{AR}_{\mathrm{w} 741 \mathrm{~L}}$ variant (Figure 1A). Importantly, an siRNA targeted specifically to the linker region between the FLAG-tag and translation start site of the $\mathrm{AR}_{\mathrm{w} 741 \mathrm{~L}}$ transcript markedly depleted the ectopically-expressed protein, but failed to impact on endogenous $\mathrm{AR}_{\mathrm{T} 877 \mathrm{~A}}$. 
A.

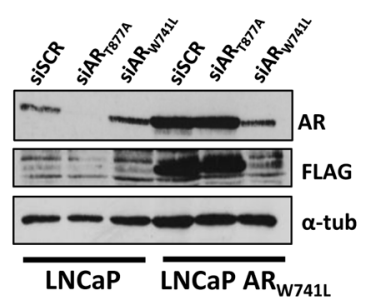

B.

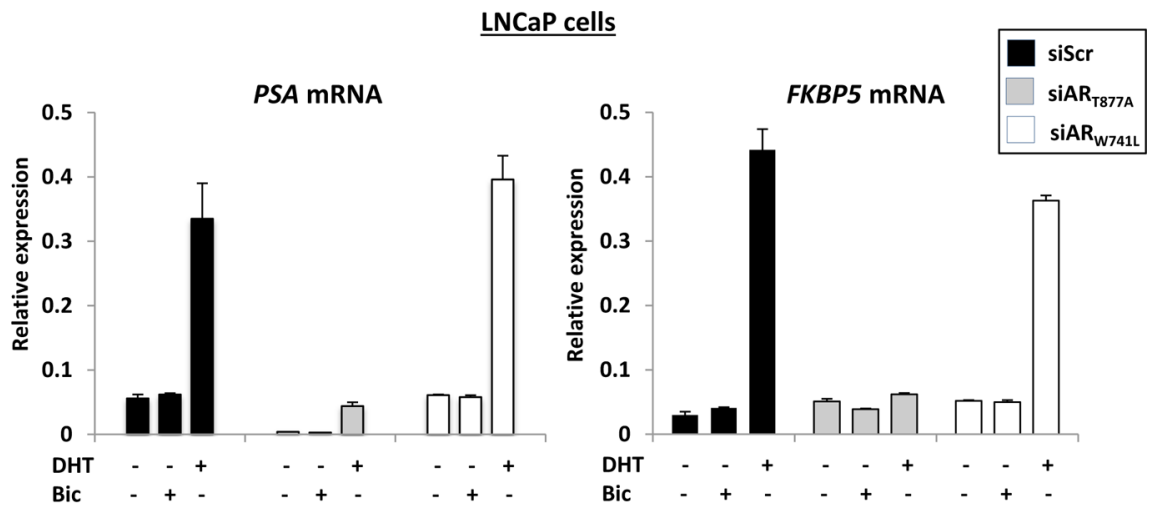

C.

$\underline{\text { LNCaP-AR}_{\text {W741L }}} \underline{\text { cells }}$
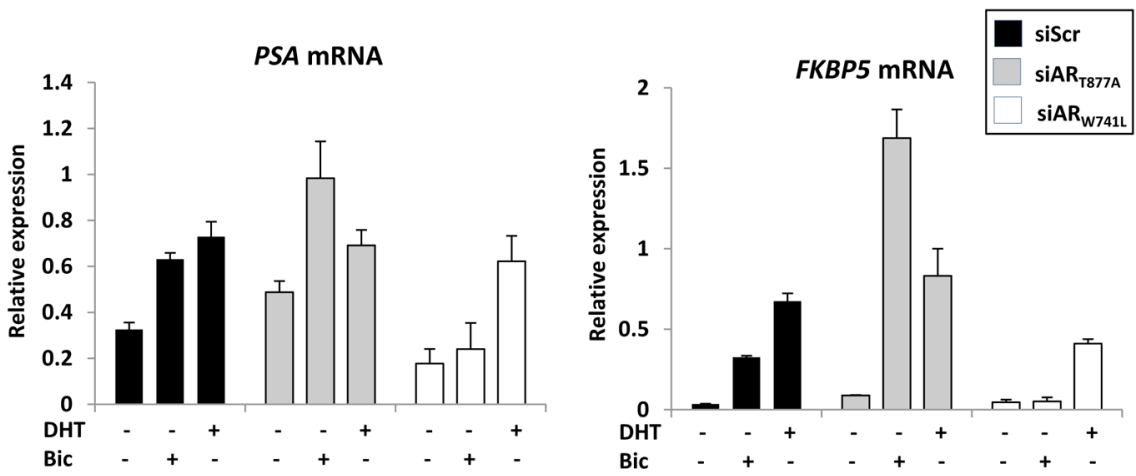

Figure 1: Stably-integrated $\mathrm{AR}_{\mathrm{w} 741 \mathrm{~L}}$ in LNCaP cells up-regulates endogenous $P S A$ and $F K B P 5$ in the presence of bicalutamide. A. Western analysis of parental and $\mathrm{AR}_{\mathrm{W} 741 \mathrm{~L}}$-expressing $\mathrm{LNCaP}$ cells depleted of either endogenous ( $\left.\mathrm{siAR}_{\mathrm{T} 877 \mathrm{~A}}\right)$ or ectopic $\left(\operatorname{siAR}_{\mathrm{w} 741 \mathrm{~L}}\right)$ receptors using $\mathrm{AR}, \mathrm{FLAG}$ (to detect FLAG-tagged $\mathrm{AR}_{\mathrm{w} 741 \mathrm{~L}}$ ) and $\alpha$-tubulin antibodies. Scrambled siRNA (siScr) was used as a transfection control. Quantitative PCR analysis of PSA and FKBP5 expression in parental LNCaP cells B. and the LNCaP-AR w74lL $_{2}$ derivative C. depleted of either endogenous or ectopic receptors treated with $1 \mathrm{nM}$ DHT or $10 \mathrm{nM}$ bicalutamide for 24 hours. Data represents the mean of three independent experiments \pm standard error.

To assess if expression of the bicalutamide-activated mutant impacts on the behaviour of the LNCaP derivative cell line, we firstly investigated the expression of known AR target genes PSA, FKBP5 (Figure 1B), KLK2 and TMPRSS2 (Supplementary Figure S4) in the presence and absence of $1 \mathrm{nM}$ DHT, $10 \mathrm{nM}$ bicalutamide (proproliferative dose; see Supplementary Figure S5) or vehicle control and compared to parental LNCaP cells. As expected, AR-target gene expression was up-regulated by DHT, but not bicalutamide, in LNCaP cells and this effect could be negated by depletion of endogenous $\mathrm{AR}_{\mathrm{T} 877 \mathrm{~A}}$ (Figure $1 \mathrm{~B}$ and Supplementary Figure S4A). In contrast, both DHT and bicalutamide enhanced transcription in LNCaP$\mathrm{AR}_{\mathrm{W} 741 \mathrm{~L}}$ cells, and depletion of $\mathrm{AR}_{\mathrm{T} 877 \mathrm{~A}}$ further increased bicalutamide-activated FKBP5 and TMPRSS2 expression (Figure 1C and Supplementary Figure S4B), suggesting a potential inhibitory role of $\mathrm{AR}_{\mathrm{T} 877 \mathrm{~A}}$ when both receptors are co-expressed. The effect of bicalutamide on these genes was specific to the $\mathrm{AR}_{\mathrm{w} 741 \mathrm{~L}}$ variant as knockdown using the siAR $_{\mathrm{W} 741 \mathrm{~L}}$ oligonucleotide abolished anti-androgen-driven transcription, but still enabled endogenous $\mathrm{AR}_{\mathrm{T} 877 \mathrm{~A}}$ to drive gene expression in the presence of DHT (Figure 1C and Supplementary Figure S4B).

\section{Bicalutamide-activated $A R_{w 741 L}$ is recruited to AR-target genes and enhances cell proliferation}

We next investigated recruitment of $\mathrm{AR}_{\mathrm{w} 741 \mathrm{~L}}$ to endogenous cis-regulatory elements of the AR-target genes PSA and TMPRSS2 in response to $1 \mathrm{nM}$ DHT and $10 \mathrm{nM}$ bicalutamide using a FLAG antibody. In cells expressing both AR variants (siSCR), DHT and bicalutamide activated a subtle increase in recruitment of FLAG-AR ${ }_{\mathrm{w} 741 \mathrm{~L}}$ to these loci (Figure 2A). Consistent with gene expression data (Figure 1), depletion of endogenous $\mathrm{AR}_{\mathrm{T} 877 \mathrm{~A}}$ markedly elevated bicalutamide-activated $\mathrm{AR}_{\mathrm{w} 741 \mathrm{~L}}$ recruitment to the PSA enhancer and TMPRSS2 promoter and this effect was diminished upon ectopic $\mathrm{AR}_{\mathrm{w} 741 \mathrm{~L}}$ knockdown. Moreover, $\mathrm{AR}_{\mathrm{w} 741 \mathrm{~L}}$ is also recruited to the promoter of the KLK2 gene in response to bicalutamide and this can be attenuated with 
A.

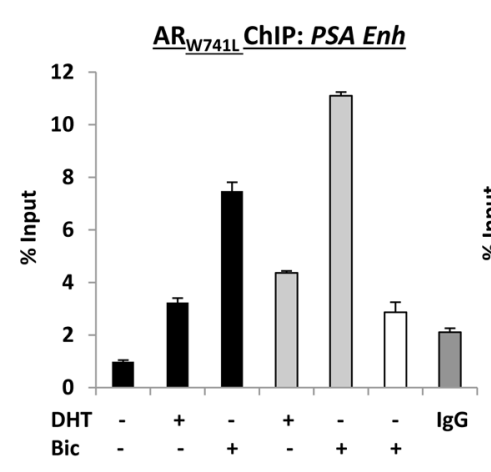

B.
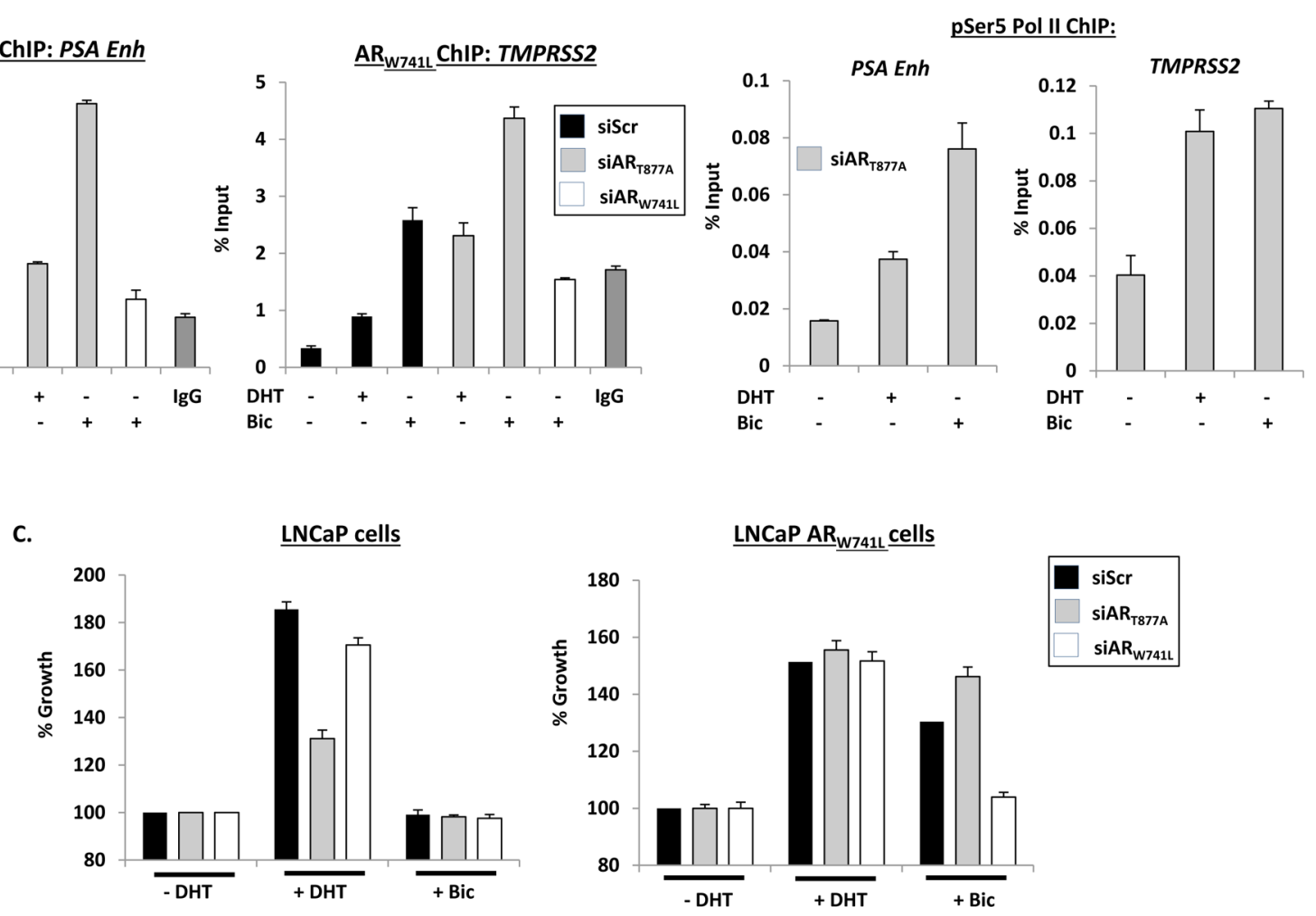

Figure 2: $\mathrm{AR}_{\mathrm{w} 741 \mathrm{~L}}$ is recruited to cis-regulatory elements of $\mathrm{AR}$-target genes and drives a pro-proliferative phenotype in response to bicalutamide. $\mathrm{A}$. $\mathrm{LNCaP}-\mathrm{AR}_{\mathrm{w} 74 \mathrm{~L}}$ cells depleted of either endogenous or ectopic $\mathrm{AR}$ were treated with $1 \mathrm{nM}$ DHT or $10 \mathrm{nM}$ bicalutamide for 4 hours prior to chromatin immunoprecipitation (ChIP) analysis using a FLAG antibody to immunoprecipitate FLAG-AR $_{\text {w74lL }}$. Receptor recruitment to the PSA enhancer (PSA Enh) and TMPRSS2 promoter was assessed by quantitative PCR. B. $\mathrm{LNCaP}-\mathrm{AR}_{\mathrm{W} 74 \mathrm{LL}}$ cells depleted of endogenous receptor and treated with $1 \mathrm{nM} \mathrm{DHT}$ or $10 \mathrm{nM}$ bicalutamide for 4 hours were subject to ChIP analysis using a phospho-Serine 5 RNA polymerase II antibody (pSer5 Pol II) and enrichment at PSA and TMPRSS2 genes measured by quantitative PCR. C. LNCaP cells or the $\mathrm{LNCaP}_{-\mathrm{AR}_{\mathrm{w} 74 \mathrm{~L}}}$ derivative depleted of endogenous or ectopic AR were grown in the presence of $1 \mathrm{nM}$ DHT or $10 \mathrm{nM}$ bicalutamide for 96 hours prior to SRB staining. Percentage growth is relative to vehicle control for each siRNA. Data is the mean of triplicate experiments \pm standard error.

ectopic receptor knockdown (Supplementary Figure S6). Importantly, using a phospho-serine 5 RNA polymerase II antibody as a marker of transcriptional initiation, we found that DHT- and bicalutamide-activated $\mathrm{AR}_{\mathrm{w} 74 \mathrm{~L}}$ can facilitate the assembly of the transcriptional machinery to drive expression of endogenous PSA and TMPRSS2 genes (Figure 2B).

We next examined the effect of $\mathrm{AR}_{\mathrm{w} 741 \mathrm{~L}}$ on proliferation of the $\mathrm{LNCaP}-\mathrm{AR}_{\mathrm{w} 74 \mathrm{~L}}$ derivative cell line in response to $1 \mathrm{nM}$ DHT and $10 \mathrm{nM}$ bicalutamide, and compared to parental LNCaP cells. As shown in Figure $2 \mathrm{C}$, growth of $\mathrm{LNCaP}$ cells was increased by DHT and this effect was reduced by $\operatorname{siAR}_{\mathrm{T} 877 \mathrm{~A}}$, but not siAR $_{\text {w741L }}$. In contrast, growth of $\mathrm{LNCaP}-\mathrm{AR}_{\mathrm{W} 741 \mathrm{~L}}$ was markedly increased in the presence of both DHT and bicalutamide and only depletion of $\mathrm{AR}_{\mathrm{W} 741 \mathrm{~L}}$ abolished bicalutamide-driven growth of these cells. To demonstrate that these findings were not an artefact of this specific clonal population of $\mathrm{AR}_{\mathrm{w} 741 \mathrm{~L}}$-expressing cells, we tested an additional selected derivative (Clone 2) against the original (Clone 1; utilised in all previous experiments) and a control transduced cell line (LNCaP-LacZ) that does not overexpress $\mathrm{AR}_{\mathrm{w} 741 \mathrm{~L}}$. Importantly, both Clone 1 and Clone 2 showed comparable growth stimulation in response to DHT and bicalutamide and was distinct from LNCaP-LacZ that only responded to DHT (Supplementary Figure S7).

\section{$A R_{w 741 \mathrm{~L}}$ is inactivated by enzalutamide}

Enzalutamide has shown great promise in the clinic [25], but the fact that not all patients respond to the drug may indicate the existence of a pre-determinant, such as an AR mutant, that compromises enzalutamide efficacy $[20,21]$. Given that enzalutamide in many cases is given as a second-line therapy post-bicalutamide treatment, it is therefore important to establish if the $\mathrm{AR}_{\mathrm{w} 74 \mathrm{LL}}$ mutant is sensitive to enzalutamide in our more robust CRPC model system. To this end, we firstly assessed the effect of $10 \mu \mathrm{M}$ enzalutamide on bicalutamide-activated $\mathrm{AR}_{\mathrm{w} 741 \mathrm{~L}}$ transcriptional activity in $\mathrm{LNCaP}-\mathrm{AR}_{\mathrm{w} 741 \mathrm{~L}}$ cells. As expected, bicalutamide up-regulated $P S A$ and $K L K 2$ 
gene expression, and importantly, this was reduced to basal levels upon administration of enzalutamide (Figure 3A). Furthermore, ChIP analysis using a FLAG antibody demonstrated that enzalutamide markedly diminished bicalutamide-activated $\mathrm{AR}_{\mathrm{W} 741 \mathrm{~L}}$ recruitment to cisregulatory elements of the PSA, TMPRSS 2 and KLK2 genes (Figure 3B and Supplementary Figure S8).

In proliferation assays, we showed that enzalutamide reduced growth of both parental and $\mathrm{AR}_{\mathrm{W} 741 \mathrm{~L}}$-expressing LNCaP cells (Figure 3C and Supplementary Figure S9). Importantly, enzalutamide attenuated bicalutamide-driven proliferation of LNCaP-AR ${ }_{\text {W741L }}$ cells (Figure 3D) indicating that this second-generation anti-androgen is likely to be effective in CRPC patients harbouring the $\mathrm{AR}_{\mathrm{w} 741 \mathrm{~L}}$ mutation.

\section{$\mathrm{AR}_{\mathrm{w} 741 \mathrm{~L}}$ drives an androgenic signalling programme similar to $A R_{T 877 A}$}

We next tested the utility of this model to provide much needed information on the global transcriptional targets of the CRPC-relevant $\mathrm{AR}_{\mathrm{W} 741 \mathrm{~L}}$ mutant. Using
LNCaP-AR ${ }_{\text {W741L }}$ cells depleted of endogenous $\mathrm{AR}_{\mathrm{T} 877 \mathrm{~A}}$, the expression profile of $\mathrm{AR}_{\mathrm{W} 741 \mathrm{~L}}$ in response to bicalutamide was compared to vehicle treated controls and a total of 869 genes were identified as being upregulated $>1.5$ fold (Figure 4A and 4B; siAR ${ }_{\mathrm{T} 877 \mathrm{~A}}$ ). This threshold was chosen as it fell within fold change cut-offs that have been used in previous publications investigating AR signalling profiles [26-28]. As a control, LNCaP-LacZ cells were treated with $10 \mathrm{nM}$ bicalutamide and the resultant transcriptome was compared to the gene list identified in LNCaP$\mathrm{AR}_{\mathrm{W} 741 \mathrm{~L}}$ cells. Importantly, no genes were identified in the LNCaP-LacZ control line that exhibited $>1.5$ fold up-regulation in the presence of bicalutamide, suggesting that the identified set of bicalutamide-induced genes in the LNCaP-AR ${ }_{\text {W741L }}$ cells were specific to the ectopicallyexpressed receptor (Figure 4A and 4B). To refine the list of core bicalutamide-induced genes further, we incorporated an additional control in which the expression profile of bicalutamide-treated LNCaP-AR ${ }_{\mathrm{W} 741 \mathrm{~L}}$ cells depleted of $\mathrm{AR}_{\mathrm{W} 741 \mathrm{~L}}$ was examined relative to siAR $\mathrm{T}_{\mathrm{T} 77 \mathrm{~A}}$ vehicle and bicalutamide-stimulated experimental arms (Figure 4A

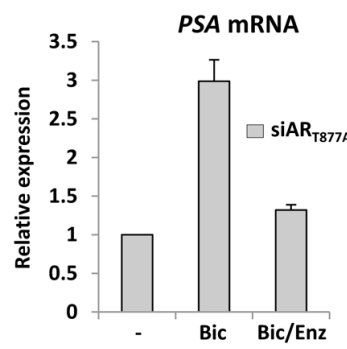

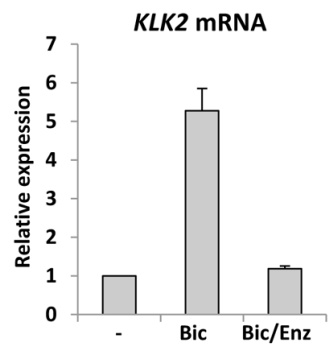

B.
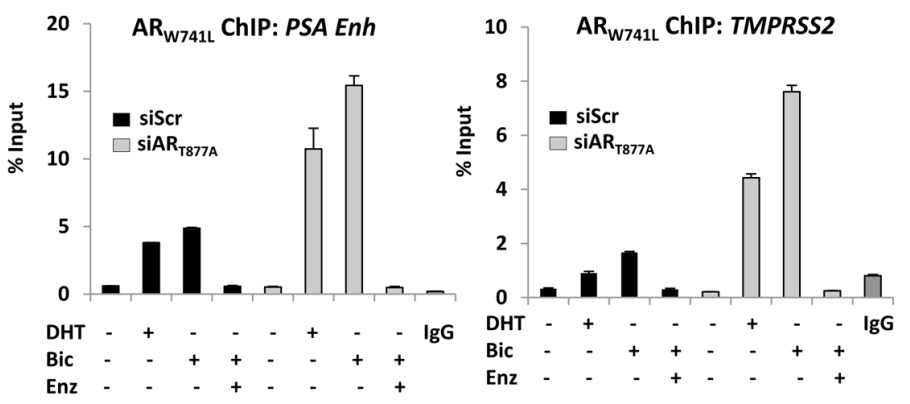

c.

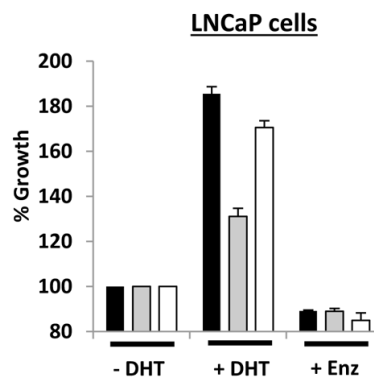

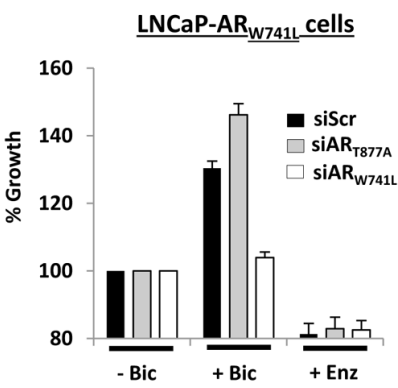

D.

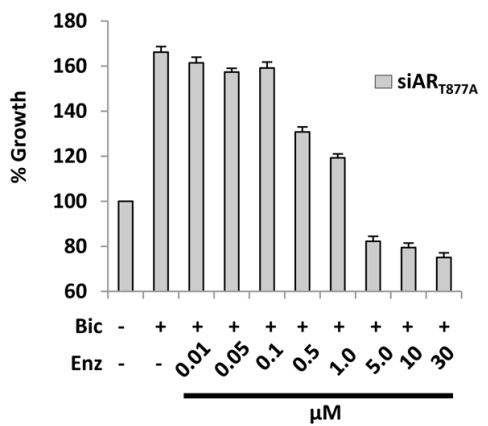

Figure 3: Bicalutamide-driven $\mathrm{AR}_{\mathrm{w} 741 \mathrm{~L}}$ activity and $\mathrm{LNCaP}-\mathrm{AR} \mathrm{R}_{\mathrm{w} 741 \mathrm{~L}}$ cell growth is attenuated by enzalutamide. A. $\mathrm{LNCaP}_{-\mathrm{AR}_{\mathrm{W} 74 \mathrm{~L}}}$ cells depleted of endogenous $\mathrm{AR}$ were treated with $10 \mathrm{nM}$ bicalutamide $+/-10 \mu \mathrm{M}$ enzalutamide for 24 hours prior to quantitative analysis of AR target gene expression. B. LNCaP-AR $_{\mathrm{W} 741 \mathrm{~L}}$ cells transfected with siScr or siAR ${ }_{\mathrm{T} 877 \mathrm{~A}}$ were treated for 4 hours with either $1 \mathrm{nM}$ DHT or bicalutamide $+/-10 \mu \mathrm{M}$ enzalutamide prior to ChIP and quantitative PCR analysis using primers specific to AR-target genes. C. LNCaP cells or the $\mathrm{LNCaP}_{-\mathrm{AR}_{\mathrm{w} 74 \mathrm{~L}}}$ derivative depleted of endogenous or ectopic AR were grown in the presence of $1 \mathrm{nM}$ DHT, $10 \mathrm{nM}$ bicalutamide or $10 \mu \mathrm{M}$ enzalutamide for 96 hours prior to SRB staining. Percentage growth is relative to vehicle control for each siRNA. Data is the mean of triplicate experiments \pm standard error. D. As for (C) except LNCaP-AR ${ }_{\mathrm{w} 741 \mathrm{~L}}$ cells depleted of endogenous AR were treated with $10 \mathrm{nM}$ bicalutamide $+/$ - increasing doses of enzalutamide to a maximum of $30 \mu \mathrm{M}$ prior to SRB staining. 


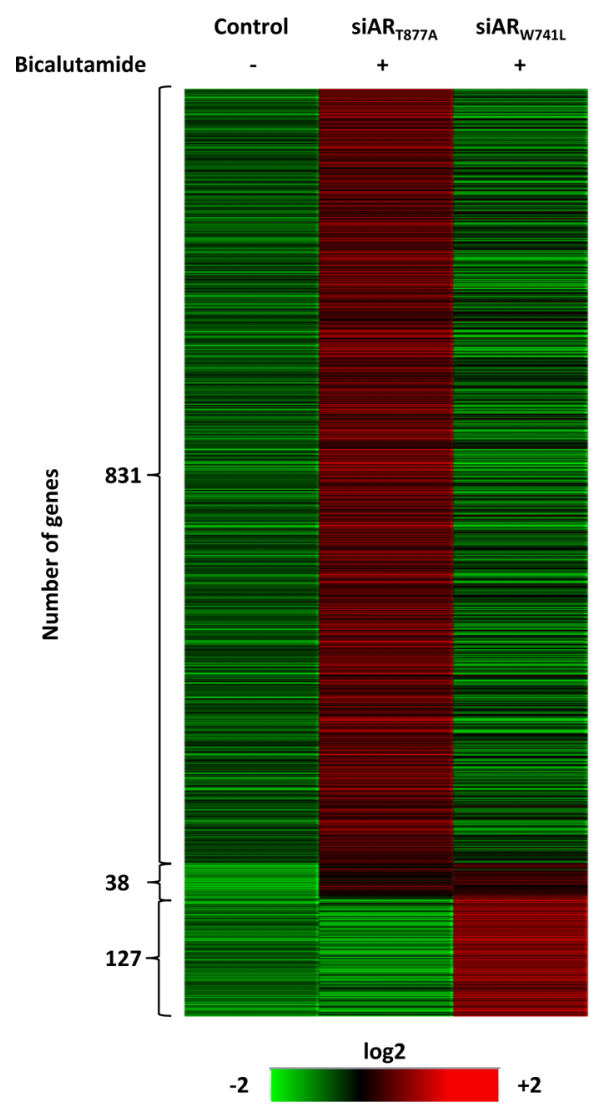

B.

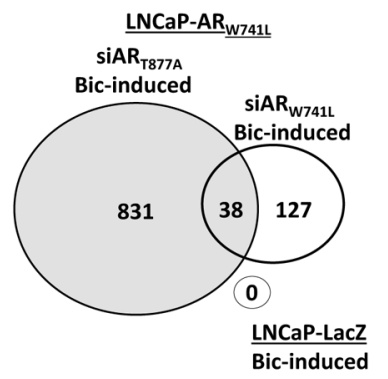

C.

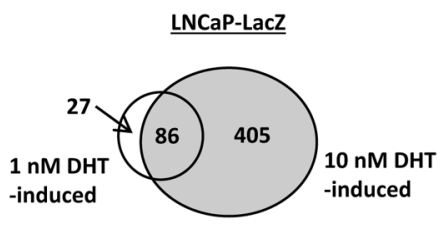

D.

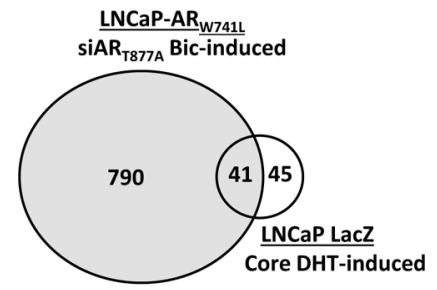

Figure 4: Bicalutamide activates an androgenic gene signature programme in $\mathbf{L N C a P - A R} \mathbf{W}_{741 \mathrm{~L}} \cdot \mathrm{LNCaP}^{-\mathrm{AR}} \mathrm{w}_{\mathrm{W} 71 \mathrm{~L}}$ cells depleted of either endogenous or ectopic AR were treated with $10 \mathrm{nM}$ bicalutamide for 24 hours prior to micro-array analysis. Resultant transcriptome was compared to control LNCaP-LacZ cells treated with $10 \mathrm{nM}$ bicalutamide. Genes with a fold increase of $>1.5$ were considered to be ligand regulated and included in the analysis. Genes with a bicalutamide-induced fold increase of $>2.0$ in the $\mathrm{AR}_{\mathrm{w} 74 \mathrm{LL}}{ }^{-}$ depleted experimental arm were eliminated from the core list of bicalutamide-induced genes. Data is presented as a heat map A. and Venn diagram B, C. LNCaP-LacZ control cells were treated with either 1 or $10 \mathrm{nM} \mathrm{DHT}$ for 24 hours prior to micro-array analysis to identify a core of DHT-regulated genes between each condition. D. Overlap between bicalutamide-induced $\mathrm{AR}_{\mathrm{w} 74 \mathrm{LL}}$ transcriptome and the identified set of 86 core DHT-up-regulated genes in the LNCaP-LacZ cells.

and $\left.4 \mathrm{~B} ; \operatorname{siAR}_{\mathrm{w} 741 \mathrm{~L}}\right)$. Genes that exhibited $>2$ fold increase in expression following bicalutamide treatment in $\mathrm{AR}_{\mathrm{W} 741 \mathrm{~L}}$-depleted cells were deemed to be bicalutamideindependent. We identified 38 genes matching to the 869 core data set that were subsequently eliminated (Figure $4 \mathrm{~A}$ and $4 \mathrm{~B}$ ); resulting in a refined gene set of 831 genes whose expression were considered to be specifically driven by bicalutamide-activated $\mathrm{AR}_{\mathrm{W} 741 \mathrm{~L}}$. The full list of bicalutamide-induced genes are listed in Supplementary Table S4 and include characterised AR-target genes such as PSA, KLK2, TMPRSS2, NKX3.1, KCNN2 and SPOCK1

We next compared the bicalutamide-driven transcriptome of $\mathrm{LNCaP}-\mathrm{AR}_{\mathrm{w} 741 \mathrm{~L}}$ with the DHTstimulated LNCaP-LacZ cell line derivative. In response to 1 and $10 \mathrm{nM}$ DHT, microarray analysis revealed 113 and 491 up-regulated genes, respectively, relative to vehicle control (Figure 4C; Supplementary Tables S5 and S6). Comparison of both gene lists found 86 common genes $(76 \%$ and $17 \%$ of $1 \mathrm{nM}$ and $10 \mathrm{nM}$ DHT up-regulated genes, respectively), highlighting a core set of androgen-regulated target genes that are activated in response to both $1 \mathrm{nM}$ and $10 \mathrm{nM}$ DHT (Figure 4C). As expected, a greater number of genes were activated in response to $10 \mathrm{nM}$ DHT than $1 \mathrm{nM}$ DHT, including FKBP5 (Supplementary Figure S10).

Direct comparison of the bicalutamide-induced LNCaP-AR ${ }_{\text {W741L }}$ expression profile to the core set of androgen-regulated genes in LNCaP-LacZ, found that 41 of the 86 genes (48\%) were common to both lists (Figure 4D). For example, PSA (KLK3) and KLK2, which were found to be the most DHT-stimulated in LNCaP-LacZ cells were also elevated in response to bicalutamide in $\mathrm{LNCaP}_{-\mathrm{AR}_{\mathrm{W} 741 \mathrm{~L}}}$ cells and is consistent with LNCaP-AR ${ }_{\text {W741L }}$ gene expression data (Figure 1C). We next compared the bicalutamide-activated $\mathrm{AR}_{\mathrm{w} 741 \mathrm{~L}}$ transcriptome with two published androgenic gene signatures acquired from LNCaP cells [27, 29]. Of the respective 21 and 79 androgen-induced genes identified in the two studies, 15/21 (71\%) and 52/79 (66\%) matched directly to genes identified in the bicalutamide-activated 
LNCaP-AR $_{\text {w741L }}$ data-set (Supplementary Figure S11; see Supplementary Table S7), indicating robust commonality between the bicalutamide-induced $\mathrm{AR}_{\mathrm{w} 741 \mathrm{~L}}$ and DHTstimulated $\mathrm{AR}_{\mathrm{T} 877 \mathrm{~A}}$ transcriptional programmes.

\section{Exploiting $\mathrm{AR}_{\mathrm{W} 741 \mathrm{~L}}$-driven $S G K 1$ expression to inactivate CRPC cell growth}

We next focused our attention on identifying $\mathrm{AR}_{\mathrm{w} 741 \mathrm{~L}}$-driven genes that were significantly elevated in response to bicalutamide and distinct from our DHT-stimulated LNCaP-LacZ transcriptome to define biomarkers of this specific CRPC-associated AR mutation and potentially highlight avenues for therapeutic exploitation. Of the top 20 bicalutamide up-regulated genes in $\mathrm{LNCaP}^{-\mathrm{AR}_{\mathrm{w} 741 \mathrm{~L}}}$ cells (Figure $5 \mathrm{~A}$ ), several were well known AR target genes, including FKBP5 and $N D R G 1$, and are elevated in response to $10 \mathrm{nM}$ DHT treatment in our LNCaP-LacZ control line (Supplementary Table S6). Importantly, array data indicated that TIPARP (TCDD-inducible poly(ADP-ribose) polymerase), RASDI (Ras dexamethasone-induced 1) and SGK1 (serum- and glucocorticoid-regulated kinase 1) were exclusively and markedly up-regulated by bicalutamide in the LNCaP$\mathrm{AR}_{\mathrm{W} 741 \mathrm{~L}}$ cell line compared to the DHT-stimulated control LNCaP-LacZ derivative (data not shown). Robust bicalutamide-mediated up-regulation of TIPARP (57-fold), RASD1 (93-fold) and SGK1 (109.5-fold) was validated by QPCR, and demonstrated to be exclusively mediated by $\mathrm{AR}_{\mathrm{w} 741 \mathrm{~L}}$ as depletion of this mutant by siAR $\mathrm{w}_{\mathrm{w} 74 \mathrm{~L}}$ completely abrogated gene expression (Figure 5B). In contrast, treatment of LNCaP-LacZ cells with a doserange of DHT (Figure 5B and Supplementary Figure S12) only modestly increased $S G K 1$ (5-fold) and RASDI (2-fold) expression and failed to elevate TIPARP transcript levels while, as expected, $P S A$ was greatly up-regulated (Supplementary Figure S13). Moreover, analysis of an additional LNCaP derivative that ectopically expresses wild-type AR (LNCaP-wtAR) to levels comparable to that of $\mathrm{AR}_{\mathrm{W} 741 \mathrm{~L}}$ (data not shown), demonstrated modest enhancement of SGK1, TIPARP and RASD1 transcription in response to DHT stimulation with respective 4.5-, 8.6- and 5.9-fold induction, indicating that the robust upregulation of the three genes in $\mathrm{LNCaP}-\mathrm{AR}_{\mathrm{w} 741 \mathrm{~L}}$ cells is not due to the phenomenon of elevated cellular AR levels (Supplementary Figure S14).

To investigate further the discriminate enhancement of TIPARP, RASDI and SGK1 by $\mathrm{AR}_{\mathrm{w} 741 \mathrm{~L}}$, we profiled expression of these genes in the $\mathrm{KUCaP}$ xenograft CRPC model. This xenograft was derived from a liver metastasis present in a bicalutamide-resistant CRPC patient and exclusively expresses the $\mathrm{AR}_{\mathrm{W} 741 \mathrm{C}}$ mutation [30]. As shown in Figure 5C, expression of TIPARP, RASD1 and SGK1 were markedly elevated in $\mathrm{KUCaP}$ cells compared to the LNCaP line confirming that key distinctions exist between transcriptomes of $\mathrm{AR}_{\mathrm{W} 741 \mathrm{~L}}$ and $\mathrm{AR}_{\mathrm{T} 877 \mathrm{~A}}$ that could be important in the pathobiology of disease in CRPC patients harbouring the bicalutamide-resistant mutation.

To address if the distinct gene-set of $\mathrm{AR}_{\mathrm{w} 74 \mathrm{LL}}$ could be exploited to provide key targets for CRPC therapy, we focussed on the potent up-regulation of $S G K 1$ expression by this mutant receptor. Given that a previous study indicated that inactivation of SGK1 using the selective inhibitor GSK650394 reduces SGK1 expression and LNCaP cell growth [31], we hypothesised that the LNCaP-AR $\mathrm{A}_{\text {74lL }}$ derivative may be sensitive to this agent as they demonstrate markedly elevated $S G K 1$ expression compared to our LNCaP control cells (Figure 5B). To this end, we assessed $\mathrm{AR}_{\mathrm{w} 741 \mathrm{~L}}$-driven expression of $S G K 1$ in the presence and absence of $10 \mu \mathrm{M}$ GSK650395; a dose demonstrated to down-regulate SGK1 transcript levels in LNCaP cells [31]. As shown in Figure 6A, treatment of LNCaP-AR w741L $_{\text {L }}$ cells with GSK650395 reduced expression of $S G K 1$ by approximately $50 \%$ indicating that activity of the bicalutamide-activated receptor is potentiated by SGK1 and attenuation of the associated kinase activity down-regulates $\mathrm{AR}_{\mathrm{w} 741 \mathrm{~L}^{-}}$ mediated transcription. Importantly, SGK1 inhibition reduced $\mathrm{LNCaP} \mathrm{AR}_{\mathrm{w} 741 \mathrm{~L}}$ proliferation by approximately $70 \%$ (Figure 6B) indicating SGK1 is a key down-stream effector of $\mathrm{AR}_{\mathrm{W} 741 \mathrm{~L}}$-driven cell growth.

Finally, we conducted a systematic in silico analysis of a comprehensive PC cohort containing 150 primary tumour samples [32] and identified one patient biopsy expressing the $\mathrm{AR}_{\mathrm{W} 741 \mathrm{C}}$ mutation. Consistent with our findings from the $\mathrm{LNCaP}_{\mathrm{A}} \mathrm{AR}_{\mathrm{w} 741 \mathrm{~L}}$ derivative and KUCaP xenograft, $S G K 1$ gene expression was found to be significantly up-regulated in this sample compared to all other samples suggesting that this may be a bona fide biomarker for aberrant $\mathrm{AR}_{\mathrm{w} 741 \mathrm{~L}}$ function (Figure $6 \mathrm{C}$ and Supplementary Figure S15) and manipulating activity of this enzyme may provide an additional means of treatment for CRPC patients resistant to bicalutamide.

\section{DISCUSSION}

The selection of AR mutations during androgendepravation therapy is a well-defined mechanism of therapy resistance that, to date, has been reported to occur in upwards of $60 \%$ advanced CRPC patients $[14,15]$. Although unclear, this figure may increase further due to two key developments: (i) the utility of more sensitive approaches for detecting mutations in both diagnostic and basic research [32], and (ii) ease of access to disseminated disease through the study of circulating tumour cells that offers a non-invasive means for $A R$ sequencing in CRPC $[33,34]$. Importantly, the presence of mutant AR in CRPC poses particular clinical challenges as many of the identified mutations promote promiscuous receptor activity that enable androgenic signalling by non-conventional ligands, including bicalutamide, flutamide [14], and more recently, enzalutamide/ARN-509 [10, 21]; hence limiting 
B.

A.

\begin{tabular}{|c|c|}
\hline \multicolumn{2}{|c|}{ LNCaP-AR } \\
W741 \\
Top 20 Bic-induced genes \\
\hline Gene ID & fold change \\
\hline RASD1 & 62.43 \\
\hline TIPARP & 23.53 \\
\hline SGK & 22.69 \\
\hline SGK1 & 21.37 \\
\hline TUBA3E & 20.83 \\
\hline SLC16A6 & 17.63 \\
\hline NCAPD3 & 13.96 \\
\hline NDRG1 & 13.12 \\
\hline ANKRD37 & 10.12 \\
\hline EAF2 & 9.52 \\
\hline FKBP5 & 9.52 \\
\hline ERRFI1 & 9.49 \\
\hline TRIM48 & 9.22 \\
\hline SCNN1G & 8.43 \\
\hline MERTK & 7.75 \\
\hline TUBA3D & 7.69 \\
\hline KLF5 & 7.10 \\
\hline LIFR & 6.91 \\
\hline FAM105A & 6.50 \\
\hline RHOU & 6.30 \\
\hline & \\
\hline
\end{tabular}

$\underline{\text { LNCaP cells }}$
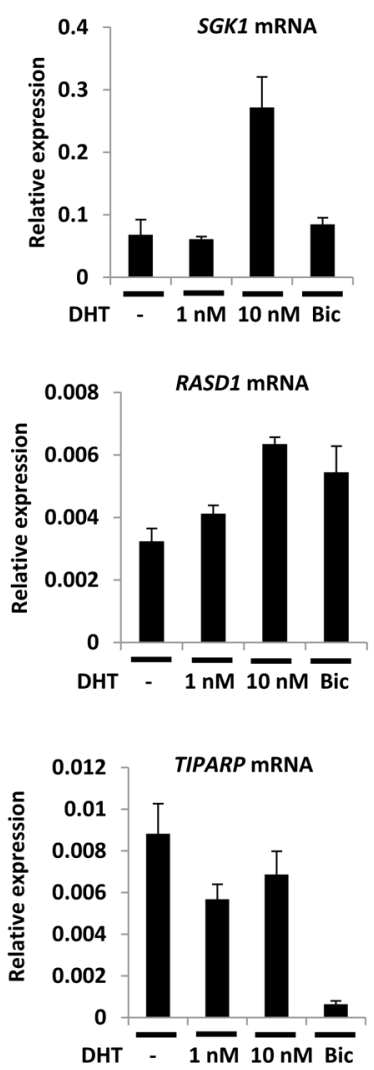

$\underline{\text { LNCaP-AR }}_{\text {W741L }} \underline{\text { cells }}$
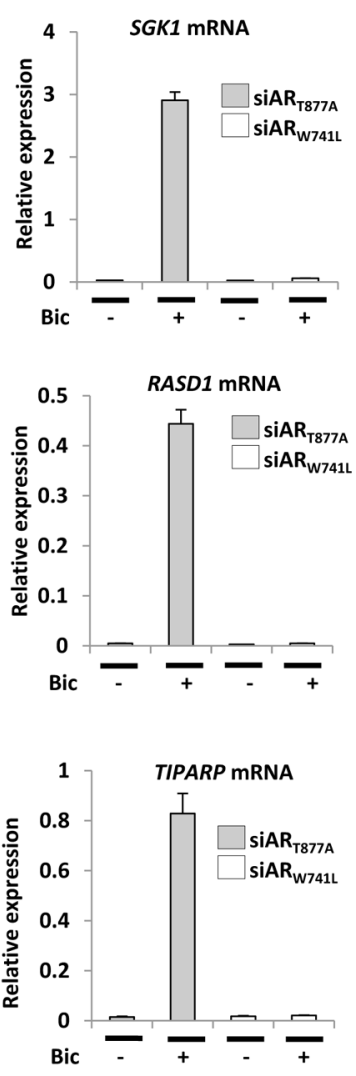

c.
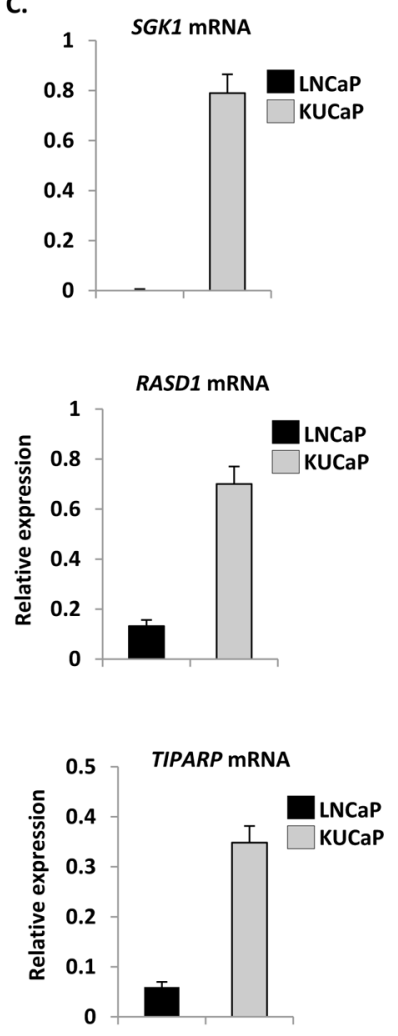

Figure 5: $\mathbf{A} \mathbf{R}_{\mathrm{W} 741 \mathrm{~L}}$ markedly up-regulates genes distinct from endogenous $\mathbf{A} \mathbf{R}_{\mathrm{T} 877 \mathbf{A}^{*}} \mathbf{A}$. Top 20 bicalutamide-induced genes identified in SiAR ${ }_{\text {T877A }}$-transfected $\mathrm{LNCaP}_{-\mathrm{AR}_{\mathrm{W} 741 \mathrm{~L}}}$ cells. B. LNCaP cells and LNCaP-AR ${ }_{\mathrm{W} 741 \mathrm{~L}}$ depleted of endogenous or ectopic receptors, were treated with either DHT (1 and $10 \mathrm{nM})$ or $10 \mathrm{nM}$ bicalutamide for 24 hours prior to quantitative analysis of $S G K 1$, RASD1 and TIPARP expression. C. Expression analysis of the same genes was compared between $\mathrm{LNCaP}^{\mathrm{cells}}$ and the $\mathrm{AR}_{\mathrm{w} 741 \mathrm{C}}{ }^{-}$ expressing KUCaP xenograft model.

available treatment options in advanced disease. From a biological perspective, our understanding of the global functioning of these aberrant receptors is remarkably limited. Outside of studies in the PC cell lines LNCaP, that harbour the $\mathrm{AR}_{\mathrm{T} 877 \mathrm{~A}}$ mutation, and CWR22RV1, that express $\mathrm{AR}_{\mathrm{H} 874 \mathrm{Y}}$ and also numerous alternatively spliced $\mathrm{AR}$ isoforms, there is a reliance upon transient expression of mutant receptors in non-androgenic cell lines to study, in most cases, the transcriptional dynamics of these proteins [23, 24]. Although useful, these experiments offer little or no insight into global transcriptomics of AR mutants and lack physiological context. Given the prevalence of AR mutations in advanced CRPC, defining their activity in more robust and disease-relevant models is imperative to help improve our understanding of these receptors and to potentially exploit their distinct activities for the development of new PC treatments.

To this end, we developed a novel RNAi-rescue system to enable the study of AR mutants in the physiological background of LNCaP cells that have been depleted of the endogenous receptor. Using the bicalutamide-activated $\mathrm{AR}_{\mathrm{W} 741 \mathrm{~L}}$ as a proof of concept mutation, that is also clinically-relevant, we generated an $\mathrm{LNCaP}$ cell line derivative that stably-expressed this mutant receptor $\left(\mathrm{LNCaP}-\mathrm{AR}_{\mathrm{W} 741 \mathrm{~L}}\right)$ and developed key siRNAs to deplete either endogenous or ectopic $\mathrm{AR}_{\mathrm{T} 877 \mathrm{~A}}$ and $\mathrm{AR}_{\mathrm{W} 741 \mathrm{~L}}$, respectively. Using this model, we demonstrated that in the presence of bicalutamide, $\mathrm{AR}_{\mathrm{W} 741 \mathrm{~L}}$ associates with cis-regulatory elements of several AR target genes, including PSA and TMPRSS2, and facilitates their expression. Significantly, these effects were attenuated upon depletion of the ectopic receptor indicating that the bicalutamide-driven functionality of $\mathrm{AR}_{\mathrm{w} 741 \mathrm{~L}}$ previously characterised in AR null cell line studies (Supplementary Figure S1 and [35]) has been phenocopied in LNCaP cells with promotion of chromatin-binding and endogenous target gene expression by the anti-androgen akin to the DHT-activated endogenous $\mathrm{AR}_{\mathrm{T} 877 \mathrm{~A}}$ isoform. Interestingly, data from both chromatin immunoprecipitation and candidate gene expression analysis (PSA, TMPRSS2, $K L K 2$ ) experiments demonstrated an inhibitory effect of $\mathrm{AR}_{\mathrm{T} 877 \mathrm{~A}}$ on bicalutamide-activated $\mathrm{AR}_{\mathrm{W} 741 \mathrm{~L}}$ when both receptor isoforms were expressed (siScr control; Figures 1 and 2). We hypothesise that dimerization between the two distinct proteins may occur in the presence of bicalutamide and impact on their activity; homodimers of $\mathrm{AR}_{\mathrm{W} 741 \mathrm{~L}}$ 
A.

$\underline{\text { LNCaP-AR }} \underline{\underline{\text { W741L }}} \underline{\underline{\text { cells }}}$

SGK1 mRNA

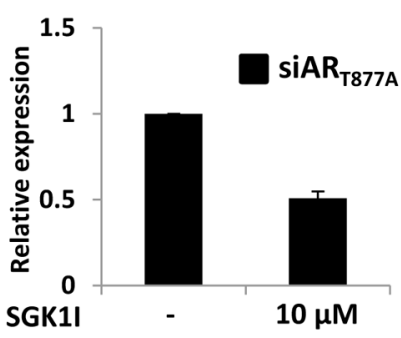

B.

$\underline{\text { LNCaP-AR }_{\text {W741L }}} \underline{\underline{\text { cells }}}$
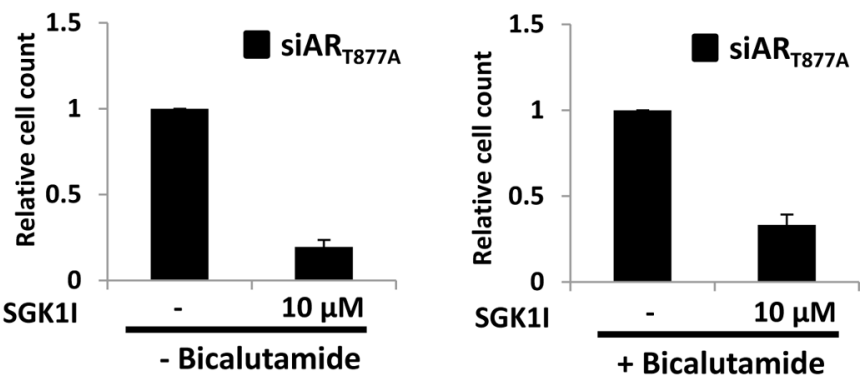

c.

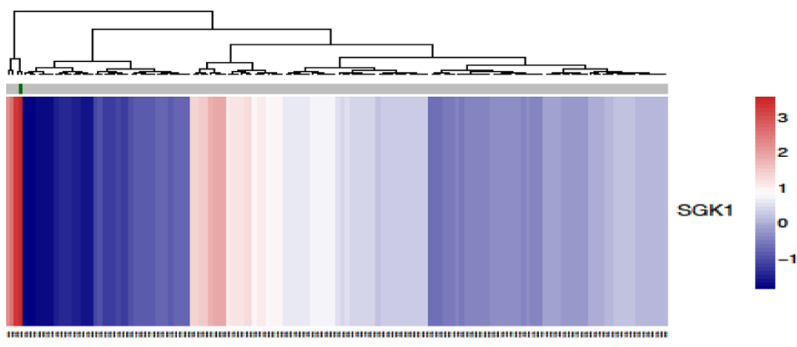

$\underset{\substack{\text { An } \\ \text { ANo }}}{\substack{\text { Noo } \\ \text { Yon }}}$

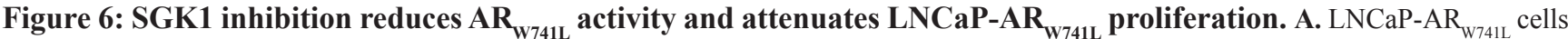
depleted of $\mathrm{AR}_{\mathrm{T} 877 \mathrm{~A}}$ were treated with $10 \mu \mathrm{M} \mathrm{SGK}$ inhibitor GSK650395 for 24 hours prior to quantitative analysis of SGK1 expression. B. As above, but cells were treated with GSK650395 for 96 hours in the presence and absence of $10 \mathrm{nM}$ bicalutamide prior to proliferation analysis. C. In silico SGK1, TIPARP and RASD1 expression profiling in 150 primary prostate cancer specimens (28); $\mathrm{AR}_{\mathrm{w} 741 \mathrm{C}^{-}} \mathrm{expressing}$ patient sample is indicated in green.

will be transcriptionally potent, while $\mathrm{AR}_{\mathrm{T877 \textrm {A }}}-\mathrm{AR}_{\mathrm{W} 741 \mathrm{~L}}$ heterodimers are likely to be functionally compromised. By depleting endogenous $\mathrm{AR}_{\mathrm{T} 877 \mathrm{~A}}$ from $\mathrm{LNCaP}$ cells, the equilibrium is pushed toward the generation of active $\mathrm{AR}_{\mathrm{w} 741 \mathrm{~L}}$ dimers to promote more robust AR-target gene binding and transcription.

To further support the utility of this RNAi-rescue system to model distinct CRPC-relevant AR mutations, we demonstrated that the $\mathrm{AR}_{\mathrm{w} 74 \mathrm{LL}}$ mutant promoted growth of the $\mathrm{LNCaP}$ derivative line in the presence of bicalutamide. The pro-proliferative effect of bicalutamide was solely driven by the activity of $\mathrm{AR}_{\mathrm{w} 741 \mathrm{~L}}$ confirming that the ectopic receptor replaces the activity of $\mathrm{AR}_{\mathrm{T} 877 \mathrm{~A}}$ and illustrates the ability for this model to recapitulate conditions of a bicalutamide-resistant CRPC disease state.

From these promising indications, we next tested the impact of the second-generation anti-androgen enzalutamide on mutant activity and growth of the $\mathrm{LNCaP}^{-\mathrm{AR}_{\mathrm{W} 74 \mathrm{LL}}}$ derivative. This is a particularly important experiment when one considers that new AR-targeting compounds will be applied to advanced, ADT-resistant CRPC that are likely to harbour pre-existing AR mutations [3]; hence defining efficacy of agents toward CRPCrelevant receptor mutations in a physiological model system is critical for optimal pre-clinical drug testing. In both the presence and absence of bicalutamide, $\mathrm{AR}_{\mathrm{w} 741 \mathrm{~L}^{-}}$ chromatin binding, endogenous target gene expression and $\mathrm{LNCaP} \mathrm{AR}_{\text {w741L }}$ growth was down-regulated by enzalutamide indicating that this mutation is sensitive to the second-generation anti-androgen. From this study, it is therefore possible to predict that patients refractory to bicalutamide through the selection of specific AR mutations are likely to demonstrate a clinical response to enzalutamide. However, given that up to $50 \%$ of patients do not respond to enzalutamide [7,25], it is likely that other pre-determinants in advanced disease may compromise AR-targeting agent efficacy; the selection of other distinct mutations during first-line ADT could represent one such mechanism of new treatment failure. Importantly, our novel rescue system would enable the robust modelling of other CRPC-relevant receptor mutants that could facilitate patient stratification towards those predicted to receive benefit from sequential anti-AR targeted therapy and those that would not.

In keeping with the utility of this model as an important pre-clinical tool to identify distinctions in the functionality of disease-associated AR mutations, we hypothesised that global transcriptomic profiling 
of $\mathrm{AR}_{\mathrm{w} 741 \mathrm{~L}}$ would provide key gene targets that could be exploited for novel CRPC treatment strategies. Examination of the bicalutamide-activated $\mathrm{AR}_{\mathrm{w} 74 \mathrm{LL}}$ target gene-set against a control transduced $\mathrm{LNCaP}$ derivative (LNCaP-LacZ) identified a series of bicalutamideinduced genes; many of which were known AR-target genes including PSA, KLK2 and TMPRSS2. Furthermore, although the number of bicalutamide-activated genes were in excess of those controlled by DHT in our control cells and those reported in Hieronymous et al., [29] and Nelson et al., [27] there was considerable overlap in the bicalutamide- and androgen-activated transcriptomes supporting the concept that $\mathrm{AR}_{\mathrm{w} 741 \mathrm{~L}}$ maintains a common androgenic expression programme. Importantly, a number of robustly up-regulated bicalutamide-dependent genes were identified by micro-array in $\mathrm{LNCaP}_{-} \mathrm{AR}_{\mathrm{w} 741 \mathrm{~L}}$ cells that were not greatly enhanced by DHT in the LNCaP-LacZ line, including TIPARP, RASDI and $S G K 1$. Depletion of ectopic receptor in $\mathrm{LNCaP}_{-} \mathrm{AR}_{\mathrm{w} 741 \mathrm{~L}}$ cells attenuated this bicalutamide-driven response indicating that these genes are potentially discriminate targets of $\mathrm{AR}_{\mathrm{w} 741 \mathrm{~L}}$. This dramatic and selective activity of the $\mathrm{AR}_{\mathrm{w} 741 \mathrm{~L}}$ mutant is intriguing and may be a consequence of subtle allosteric re-organisation of the receptor that permits hyper-activation of the receptor at distinct genomic loci. By repositioning the $\mathrm{C}$-terminal activation function-2 (AF-2) domain of the receptor, the leucine residue may enable more robust interaction with selective co-regulators to drive acetylation and methylation of the AR to enhance inherent transcriptional activity $[19,36]$.

In contrast to our data, however, SGK1 has been identified to be robustly up-regulated by endogenous $\mathrm{AR}_{\mathrm{T} 877 \mathrm{~A}}$ in $\mathrm{LNCaP}$ cells and the gene product found to positively reinforce androgenic signalling [31, 37]. The discrepancy between our data and these findings is intriguing and may reflect key differences in experimental design and performance, as although we did detect a 3 -fold and 4.5-fold enhancement of SGK1 expression in response to $10 \mathrm{nM}$ DHT by quantitative PCR in the respective LNCaP-LacZ and LNCaP-wtAR cell derivatives, it was significantly less than previous reported.

Importantly, the same study provided evidence that inactivation of SGK1 with the selective small molecule inhibitor GSK650395 was able to attenuate LNCaP cell proliferation in the presence of DHT [31]. Therefore, given that $\mathrm{LNCaP}-\mathrm{AR}_{\mathrm{w} 741 \mathrm{~L}}$ cells demonstrated marked upregulation of $S G K 1$ expression in response to bicalutamide, we speculated that they may also be sensitive to SGK1 inhibition. Consistent with the reported phenomenon in parental LNCaP cells [31], we found that $\mathrm{AR}_{\mathrm{w} 741 \mathrm{~L}}$-driven $S G K 1$ expression was down-regulated in response to GSK650395 treatment, suggesting that ectopic receptor function is dependent upon SGK1-mediated kinase activity. Furthermore, proliferation of both $\mathrm{LNCaP}$ and
$\mathrm{LNCaP}_{-\mathrm{AR}_{\mathrm{w} 741 \mathrm{~L}}}$ cells was significantly down-regulated upon SGK1 inhibition; with similar $\mathrm{IC}_{50}$ values for both cell lines in response to GSK650395 (Supplementary Figure S16). Importantly, in the $\mathrm{LNCaP}^{-\mathrm{AR}_{\mathrm{W} 741 \mathrm{~L}}}$ cells, this anti-proliferative effect was maintained in the presence of a pro-proliferative dose of bicalutamide. We have therefore identified a strongly up-regulated $\mathrm{AR}_{\mathrm{w} 741 \mathrm{~L}}$ target gene that may offer an avenue for therapeutic exploitation in bicalutamide-refractory CRPC. Although these observations are based on our rescue model system, evidence from the patient-derived $\mathrm{KUCaP}$ xenograft and a single patient biopsy sample, that both harbour the bicalutamide-activated $\mathrm{AR}_{\mathrm{w} 741 \mathrm{C}}$ mutation $[30,32]$, is in agreement with our findings of elevated $S G K 1$ expression and suggests utility of our RNAi-rescue approach to define global functionality of the $\mathrm{AR}_{\mathrm{W} 741 \mathrm{~L}}$ mutation.

In all, we have established a novel LNCaP cell line-based strategy to model CRPC-relevant mutations to provide important information on receptor dynamics and global gene signalling in response to distinct activating ligands.

\section{MATERIALS AND METHODS}

\section{Luciferase reporter, quantitative PCR and western analyses}

Luciferase assays were performed in HEK293T cells grown in steroid-depleted media as described in [38] utilising the $\mathrm{p}(\mathrm{ARE})_{3}$ reporter and pFLAG-AR, $-\mathrm{AR}_{\mathrm{w} 741 \mathrm{~L}}$ and $-\mathrm{AR}_{\mathrm{H} 874 \mathrm{Y}}$ Quantitative PCR was used to assess expression of endogenous $\mathrm{AR}$-and $\mathrm{AR}_{\mathrm{W} 74 \mathrm{LL}}$-target genes (see Supplementary Table S1 for primer sequences) using cDNA generated from Trizol-mediated RNA extractions as described in [39]. Western blotting was performed as described in [40] using antibodies listed in Supplementary Table S3.

\section{Cell proliferation assays}

Sulforhodamine B (SRB) assays were performed according to [41]. Briefly, $5 \times 10^{3} \mathrm{LNCaP}$ or LNCaP$\mathrm{AR}_{\mathrm{w} 741 \mathrm{~L}}$ cells per well of a 96-well plate grown in steroid-depleted conditions were transfected with siScr, $\mathrm{siAR}_{\mathrm{T} 877 \mathrm{~A}}$ or siAR $\mathrm{w}_{\mathrm{W} 74 \mathrm{~L}}$ for 96 hours as described above before fixing in trichloroacetic acid for 1 hour at $4{ }^{\circ} \mathrm{C}$. Cells were washed and subsequently stained with $0.4 \%$ SRB dissolved in $1 \%$ acetic acid. Plates were air dried at room temperature, after which bound SRB was dissolved in $10 \mathrm{mM}$ Tris- $\mathrm{HCl}, \mathrm{pH} 10.8$. Absorbance was measured at $570 \mathrm{~nm}$ using a 96-well plate reader (BioRad). For drug treatments, $10 \mathrm{nM}$ bicalutamide, $1 \mathrm{nM}$ DHT, or increasing doses of enzalutamide, were administered for 96 hours prior to SRB assay.

For additional Methods please refer to accompanying Supplementary Information. 


\section{ACKNOWLEDGMENTS}

We would like to thank Ralf Janknecht for supplying pCMV-FLAG-AR and Osamu Ogawa for providing KUCaP cDNA.

\section{FUNDING}

The work was supported by Cancer Research UK (DO), Medical Research Council (DJ) Worldwide Cancer Research (MW) and Prostate Cancer UK (JG).

\section{CONFLICTS OF INTEREST}

The authors declare no conflict of interest.

\section{REFERENCES}

1. Sridhar SS, Freedland SJ, Gleave ME, Higano C, Mulders P, Parker C, Sartor O, Saad F. Castration-Resistant Prostate Cancer: From New Pathophysiology to New Treatment. Eur Urol. 2013; 65:289-299.

2. Yuan X, Cai C, Chen S, Yu Z, Balk SP. Androgen receptor functions in castration-resistant prostate cancer and mechanisms of resistance to new agents targeting the androgen axis. Oncogene. 2013; 33:2815-2825.

3. Karantanos T, Evans CP, Tombal B, Thompson TC, Montironi R, Isaacs WB. Understanding the Mechanisms of Androgen Deprivation Resistance in Prostate Cancer at the Molecular Level. Eur Urol. 2014; 67:470-479.

4. Chen Y, Sawyers CL, Scher HI. Targeting the androgen receptor pathway in prostate cancer. Current opinion in pharmacology. 2008; 8:440-448.

5. Bishr M, Saad F. Overview of the latest treatments for castration-resistant prostate cancer. Nature reviews Urology. 2013; 10:522-528.

6. Waltering KK, Urbanucci A, Visakorpi T. Androgen receptor (AR) aberrations in castration-resistant prostate cancer. Mol Cell Endocrinol. 2012; 360:38-43.

7. Tran C, Ouk S, Clegg NJ, Chen Y, Watson PA, Arora V, Wongvipat J, Smith-Jones PM, Yoo D, Kwon A, Wasielewska T, Welsbie D, Chen CD, Higano CS, Beer TM, Hung DT, et al. Development of a secondgeneration antiandrogen for treatment of advanced prostate cancer. Science. 2009; 324:787-790.

8. Clegg NJ, Wongvipat J, Joseph JD, Tran C, Ouk S, Dilhas A, Chen Y, Grillot K, Bischoff ED, Cai L, Aparicio A, Dorow S, Arora V, Shao G, Qian J, Zhao H, et al. ARN-509: a novel antiandrogen for prostate cancer treatment. Cancer Res. 2012; 72:1494-1503.

9. Attard G, Reid AH, Yap TA, Raynaud F, Dowsett M, Settatree S, Barrett M, Parker C, Martins V, Folkerd E, Clark J, Cooper CS, Kaye SB, Dearnaley D, Lee G, de Bono JS. Phase I clinical trial of a selective inhibitor of CYP17, abiraterone acetate, confirms that castration-resistant prostate cancer commonly remains hormone driven. J Clin Oncol. 2008; 26:4563-4571.

10. Nelson WG, Yegnasubramanian S. Resistance emerges to second-generation antiandrogens in prostate cancer. Cancer discovery. 2013; 3:971-974.

11. Li Y, Chan SC, Brand LJ, Hwang TH, Silverstein KA, Dehm SM. Androgen receptor splice variants mediate enzalutamide resistance in castration-resistant prostate cancer cell lines. Cancer Res. 2013; 73:483-489.

12. Antonarakis ES, Lu C, Wang H, Luber B, Nakazawa M, Roeser JC, Chen Y, Mohammad TA, Fedor HL, Lotan TL, Zheng Q, De Marzo AM, Isaacs JT, Isaacs WB, Nadal R, Paller CJ, et al. AR-V7 and resistance to enzalutamide and abiraterone in prostate cancer. N Engl J Med. 2014; 371:1028-1038.

13. Visakorpi T, Hyytinen E, Koivisto $\mathrm{P}$, Tanner $\mathrm{M}$, Keinanen R, Palmberg C, Palotie A, Tammela T, Isola J, Kallioniemi OP. In vivo amplification of the androgen receptor gene and progression of human prostate cancer. Nat Genet. 1995; 9:401-406.

14. Brooke GN, Bevan CL. The role of androgen receptor mutations in prostate cancer progression. Current genomics. 2009; 10:18-25.

15. Steinkamp MP, O'Mahony OA, Brogley M, Rehman H, Lapensee EW, Dhanasekaran S, Hofer MD, Kuefer R, Chinnaiyan A, Rubin MA, Pienta KJ, Robins DM. Treatment-dependent androgen receptor mutations in prostate cancer exploit multiple mechanisms to evade therapy. Cancer Res. 2009; 69:4434-4442.

16. Dehm SM, Tindall DJ. Alternatively spliced androgen receptor variants. Endocr Relat Cancer. 2011; 18:R183-196.

17. Linja MJ, Porkka KP, Kang Z, Savinainen KJ, Janne OA, Tammela TL, Vessella RL, Palvimo JJ, Visakorpi T. Expression of androgen receptor coregulators in prostate cancer. Clin Cancer Res. 2004; 10:1032-1040.

18. Chan SC, Dehm SM. Constitutive activity of the androgen receptor. Adv Pharmacol. 2014; 70:327-366.

19. Fu M, Rao M, Wang C, Sakamaki T, Wang J, Di Vizio D, Zhang X, Albanese C, Balk S, Chang C, Fan S, Rosen E, Palvimo JJ, Janne OA, Muratoglu S, Avantaggiati ML, et al. Acetylation of androgen receptor enhances coactivator binding and promotes prostate cancer cell growth. Mol Cell Biol. 2003; 23:8563-8575.

20. Korpal M, Korn JM, Gao X, Rakiec DP, Ruddy DA, Doshi S, Yuan J, Kovats SG, Kim S, Cooke VG, Monahan JE, Stegmeier F, Roberts TM, Sellers WR, Zhou W, Zhu P. An F876L mutation in androgen receptor confers genetic and phenotypic resistance to MDV3100 (enzalutamide). Cancer discovery. 2013; 3:1030-1043.

21. Joseph JD, Lu N, Qian J, Sensintaffar J, Shao G, Brigham D, Moon M, Maneval EC, Chen I, Darimont B, Hager JH. A Clinically Relevant Androgen Receptor Mutation Confers Resistance to Second-Generation Antiandrogens Enzalutamide and ARN-509. Cancer discovery. 2013; 3:1020-1029. 
22. Balbas MD, Evans MJ, Hosfield DJ, Wongvipat J, Arora VK, Watson PA, Chen Y, Greene GL, Shen Y, Sawyers CL. Overcoming mutation-based resistance to antiandrogens with rational drug design. eLife. 2013; 2:e0499.

23. Duff J, McEwan IJ. Mutation of histidine 874 in the androgen receptor ligand-binding domain leads to promiscuous ligand activation and altered p160 coactivator interactions. Mol Endocrinol. 2005; 19:2943-2954.

24. Brooke GN, Parker MG, Bevan CL. Mechanisms of androgen receptor activation in advanced prostate cancer: differential co-activator recruitment and gene expression. Oncogene. 2008; 27:2941-2950.

25. Scher HI, Fizazi K, Saad F, Taplin ME, Sternberg CN, Miller K, de Wit R, Mulders P, Chi KN, Shore ND, Armstrong AJ, Flaig TW, Flechon A, Mainwaring P, Fleming M, Hainsworth JD, et al. Increased survival with enzalutamide in prostate cancer after chemotherapy. N Engl J Med. 2012; 367:1187-1197.

26. Arora VK, Schenkein E, Murali R, Subudhi SK, Wongvipat J, Balbas MD, Shah N, Cai L, Efstathiou E, Logothetis C, Zheng D, Sawyers CL. Glucocorticoid receptor confers resistance to antiandrogens by bypassing androgen receptor blockade. Cell. 2013; 155:1309-1322.

27. Nelson PS, Clegg N, Arnold H, Ferguson C, Bonham M, White J, Hood L, Lin B. The program of androgenresponsive genes in neoplastic prostate epithelium. Proc Natl Acad Sci U S A. 2002; 99:11890-11895.

28. Chen CD, Welsbie DS, Tran C, Baek SH, Chen R, Vessella R, Rosenfeld MG, Sawyers CL. Molecular determinants of resistance to antiandrogen therapy. Nat Med. 2004; 10:33-39.

29. Hieronymus H, Lamb J, Ross KN, Peng XP, Clement C, Rodina A, Nieto M, Du J, Stegmaier K, Raj SM, Maloney KN, Clardy J, Hahn WC, Chiosis G, Golub TR. Gene expression signature-based chemical genomic prediction identifies a novel class of HSP90 pathway modulators. Cancer Cell. 2006; 10:321-330.

30. Yoshida T, Kinoshita H, Segawa T, Nakamura E, Inoue T, Shimizu Y, Kamoto T, Ogawa O. Antiandrogen bicalutamide promotes tumor growth in a novel androgen-dependent prostate cancer xenograft model derived from a bicalutamidetreated patient. Cancer Res. 2005; 65:9611-9616.

31. Sherk AB, Frigo DE, Schnackenberg CG, Bray JD, Laping NJ, Trizna W, Hammond M, Patterson JR, Thompson SK, Kazmin D, Norris JD, McDonnell DP. Development of a small-molecule serum- and glucocorticoidregulated kinase-1 antagonist and its evaluation as a prostate cancer therapeutic. Cancer Res. 2008; 68:7475-7483.
32. Taylor BS, Schultz N, Hieronymus H, Gopalan A, Xiao Y, Carver BS, Arora VK, Kaushik P, Cerami E, Reva B, Antipin Y, Mitsiades N, Landers T, Dolgalev I, Major JE, Wilson $\mathrm{M}$, et al. Integrative genomic profiling of human prostate cancer. Cancer Cell. 2010; 18:11-22.

33. Sandhu SK, Schelman WR, Wilding G, Moreno V, Baird RD, Miranda S, Hylands L, Riisnaes R, Forster M, Omlin A, Kreischer N, Thway K, Gevensleben H, Sun L, Loughney J, Chatterjee M, et al. The poly(ADP-ribose) polymerase inhibitor niraparib (MK4827) in BRCA mutation carriers and patients with sporadic cancer: a phase 1 dose-escalation trial. The lancet oncology. 2013; 14:882-892.

34. Scher HI, Jia X, de Bono JS, Fleisher M, Pienta KJ, Raghavan D, Heller G. Circulating tumour cells as prognostic markers in progressive, castration-resistant prostate cancer: a reanalysis of IMMC38 trial data. The lancet oncology. 2009; 10:233-239.

35. Hara T, Miyazaki J, Araki H, Yamaoka M, Kanzaki N, Kusaka M, Miyamoto M. Novel mutations of androgen receptor: a possible mechanism of bicalutamide withdrawal syndrome. Cancer Res. 2003; 63:149-153.

36. Gaughan L, Stockley J, Wang N, McCracken SR, Treumann A, Armstrong K, Shaheen F, Watt K, McEwan IJ, Wang C, Pestell RG, Robson CN. Regulation of the androgen receptor by SET9-mediated methylation. Nucleic Acids Res. 2011; 39:1266-1279.

37. Shanmugam I, Cheng G, Terranova PF, Thrasher JB, Thomas CP, Li B. Serum/glucocorticoid-induced protein kinase-1 facilitates androgen receptor-dependent cell survival. Cell Death Differ. 2007; 14:2085-2094.

38. Gaughan L, Logan IR, Neal DE, Robson CN. Regulation of androgen receptor and histone deacetylase 1 by Mdm2mediated ubiquitylation. Nucleic Acids Res. 2005; 33:13-26.

39. Gaughan L, Stockley J, Coffey K, O'NeillD, Jones DL, Wade M, Wright J, Moore M, Tse S, Rogerson L, Robson CN. KDM4B is a Master Regulator of the Estrogen Receptor Signalling Cascade. Nucleic Acids Res. 2013; 41:6892-6904.

40. Rajan P, Gaughan L, Dalgliesh C, El-Sherif A, Robson C, Leung H, Elliott D. The RNA-binding and adaptor protein Sam68 modulates signal-dependent splicing and transcriptional activity of the androgen receptor. J Pathol. 2008; 215:67-77.

41. Skehan P, Storeng R, Scudiero D, Monks A, McMahon J, Vistica D, Warren JT, Bokesch H, Kenney S, Boyd MR. New colorimetric cytotoxicity assay for anticancer-drug screening. J Natl Cancer Inst. 1990; 82:1107-1112. 